\title{
Improving Women and Family's Health through Integrated Microfinance, Health Education and Promotion in Rural Areas
}

\author{
Kahabi Ganka Isangula ${ }^{1}$ \\ ${ }^{1}$ Bloomberg School of Public Health, The Johns Hopkins University, Baltimore, Maryland, USA \\ Correspondence: Kahabi Ganka Isangula, Bloomberg School of Public Health, The Johns Hopkins University, \\ Baltimore, MD, 615 N Wolfe Street, W2015, 20215, USA. Tel: 1-443-418-7605. E-mail: kisangul@jhsph.edu
}

Received: February 10, 2012 Accepted: March 26, 2012 Online Published: May 1, 2012

doi:10.5539/jsd.v5n5p76

URL: http://dx.doi.org/10.5539/jsd.v5n5p76

\begin{abstract}
While increasing number of women enjoys more freedom and power in urban areas, women in rural areas are at a disadvantage in almost all aspects of life when compared to men. Investing in economic empowerment of women particularly in rural areas by supporting them to implement local context based business ideas and basic finance capacity and skills development may reverse these trends, however, when combined with heath education and promotion through trainings focusing on preventive health yields greater impact. This paper is a systematic review of the peer - reviewed research papers and project reports in English language on how rural women, children and family's health can be improved through integrating income generation and health education \& promotion activities. Generally, integrated microfinance, health education and promotion activities has resulted in significant reduction of intimate-partner violence, reduction in HIV/AIDS risk, promotion of mental health and improved women and family health. The findings may guide the process of designing and planning of integrated programs for sustainable women's income and family health especially in rural areas.
\end{abstract}

Keywords: microfinance, women, income, empowerment, gender, health

\section{Introducation}

According to UN Statistics, there are approximately 57 million more men than women globally. A woman lives longer than a man on average however; sociocultural, political and economic inequalities diminish this natural advantage of women over men. Moreover, among 774 million illiterate adults, women account for about two third (United Nations Development Program [UNDP], 2011). With regard to poverty, more than 1.2 billion people lives in poverty, of these, about $70 \%$ are women. In terms of hours of work, women work more than men making $67 \%$ of the world's working hours surprisingly earning $10 \%$ of the income and owning $1 \%$ of property of the world. Moreover, women receive 30-40\% lower wages than men for the same level work, on average. In developing countries, women produce about $60-80 \%$ of the food. Politically, women hold about $5-20 \%$ management and administration jobs; about $5 \%$ or less of country or state headship positions in the world (United Nations, 2010). In rural areas, women are at a disadvantage in all aspects of life when compared to men, investing in the economic empowerment of rural women may reverse these trends (Kim et al., 2007). Supporting women in implementing local context based business ideas, entrepreneurship and basic finance capacity and skills development when combined with heath education and promotion through maternal, child \& family health and nutrition trainings focusing on preventive health yields greater health impact compared to programs implementing microfinance alone. Women empowerment and transformations in gender roles have enabled some countries and groups to improve equity, advancing human development and environmental sustainability (United Nations, 2010; UNDP, 2011).

Microfinance is defined as a process of providing different finance based services including loan services, deposits services, insurance services and money transfer services to the low-income and poor households and their income generating activities or micro enterprises (Asian Development Bank [ADB], 2000a). Different sources of microfinance services exist in rural areas ranging from formal, such as cooperative unions and banks; Semi-formal, such as CBOs and NGOs; and informal, such as local shopkeepers and moneylenders (ADB, 2000a; ADB, 2000b). The Asian Development Bank's microfinance definition entails households of low-income, poor and those under the line of poverty. Microfinance is a very broad term that includes loan or credit services as a product for clients, as well as grants, savings and business skills or life skills education and sometimes-vocational training. 
The primary goal of microfinance programs is to alleviate poverty, under the assumption that particular groups in the population lack access to reliable and sustainable financial resources and services that could help them to improve individual and family's standard of living (ADB, 1998; ADB, 2000a). Providing microfinance services to low income individual will not only benefit the poor, socially and economically disadvantaged, through more opportunities for self-employment, but also increasing accessibility and lowering cost of goods and services, especially health care services. While these low-income and poor households has limited financial service access, the demand for safe, reliable and convenient deposit services is overwhelming, evidenced by the poor people's saving capacity, desire and willingness for emergencies, social obligations, family and children's health, children's education and many other purposes (ADB, 2000a; Vrajlal, 2010).

The common type of microfinance especially in rural areas is microcredit, in which organizations offers a small loan to a borrower, to support growth of her small-scale business or start a new business endeavor. These small loans or micro credits are often paid back in agreed time, say daily, weekly or monthly installments (ADB, 2006; Vrajlal, 2010; Nawaz, 2010). It is obvious that microfinance firms have money lending preference over people who own tangible property or have formal jobs and most often, regard the poor as a serious credit risk however, the importance of offering microcredit services to the poor is increasingly recognized for several reasons; for instance, ADB (2000a), considers microfinance as an effective and strong strategy for poverty reduction by enabling the poor and low income households in smootherning consumption, improving risk management, enabling assets building, micro-enterprises development, enhancing income generating ability and capacity, and enjoying and improving quality of life. Again, microfinance provides an economically effective way to assist and empower poor and socially disadvantaged women and lastly, microfinance may contribute to financial system growth and development overall, especially in rural areas through "integration of financial markets".

Again, the 1995 Beijing's World Women Conference Declaration recommended that achieving gender equality and equity requires access to financial services as means of empowering impoverished and marginalized women, yet even after more than 16 years, women still constitute majority of the poor and they lack many of the resources disposed to men (United Nations Population Fund [UNFPA], 2011). Despite the fact that in urban areas, increasing number of women enjoys more freedom and power, women in rural areas are at a disadvantage and investing in the economic empowerment of rural women may reverse these trends. Socio-cultural, political, legal and economic barriers in rural areas prevent women from accessing education, finance and health services (Kim et al., 2007; UNFPA, 2011). It is documented that women and men's household-level business, financial expenditures, family level consumption plans and goals, especially in rural areas often differ significantly (ADB, 2006; Manohar, 2003). Even illiterate women have better informal finance management skills compared to men in rural areas. Moreover, resources managed by a woman affect the quality of investment activities financed by microfinance and expenditure of the income generated at individual and family level. Women are the gateway to household security, as they generally invest in the welfare of the family than do men (Manohar, 2003; UNFPA, 2011).

More evidences on women, community participation and development are now available. However, Manderson and Mark (1997) noted that microfinance project reports of most NGOs, analyses and evaluations of their failures and successes are under-disseminated and that public records lack literatures that describe or evaluate programs and interventions considered to have contributed towards improvement of access and utilization of health care services among women particularly in developing countries and these reports are not published, or made available primarily to donor or funding agencies only. The purpose of this paper is to review peer -reviewed research articles and project reports on how rural women, children and family's health can be improved through integrating income generation and health education \& promotion activities for women. The findings may guide the process of desiging and planning of integrated programs for sustainable women's income and family health especially in rural areas.

\section{Methods}

\subsection{Description of Methodological Concepts}

For the purpose of this paper, ADB's definition of microfinance was used, that is a process of providing different finance based services including loan services, deposit services, insurance services and money transfer services to the low-income and poor households and their income generating activities or micro enterprises (ADB, 2000a) and WHO's definition was utilized for women and family 'health' which was considered as a state of complete mental, physical and social well-being of a woman and/or family members, not merely the absence of disease (WHO, 2005). 


\subsection{Literature Search}

Peer-reviewed literatures and microfinance project reports were searched using two main strategies; a tradition Welch Library PubMed database and Google search; and searching for specific organization's microfinance project reports.

On Welch Library's PubMed, keywords used were 'microfinance gender income empowerment health' yielding 121 articles and a Google search using keywords 'microfinance+woman empowerment OR gender OR health' yielding 887 documents most of which were not consistent with the requirement of this paper.

A second strategy in literature review involved searching the program reports on the websites of different institutions involved in microfinance and women empowerment or health. These included Asian Development Bank (ADB), United Nations and WHO using a search key "microfinance women gender health". ADB advanced search resulted into 110 documents, United Nations 760 and WHO 483 reports making a total of 1353 institutional reports.

\subsection{Article/Report Selection for Literature Review}

These documents in English were filtered using inclusion and exclusion criteria to finally get 38 peer reviewed papers and 11 Institutional reports used in this paper.

Inclusion and Exclusion criteria: The peer reviewed papers and project reports considered were those published after 1991 that described how microfinance helped to empower women, reduced their gender based vulnerabilities and promoted reproductive and family health. Research articles were excluded if they 1) were published before 1992;2) reported or described urban based program with no rural involvement except for description of concepts related to the topic; 3) did not discuss microfinance, women and/or health; 4) were non peer reviewed. Program reports were excluded if, on addition to 1-3 above 1) were discussing issues other than the topic under consideration; 2) were from other institutions than mentioned; and 3) highly covered developed countries.

\section{Results}

A total of 38 peer reviewed articles and 11 project reports met the inclusion criteria and used for this paper. The following table shows the literature search results and those met criteria for review.

Table 1. Results of the literature search

\begin{tabular}{ccc}
\hline Source & Number of articles & Articles meeting Criteria \\
\hline Welch Library-Pubmed & 121 & 20 \\
Google Database & 887 & 18 \\
Asian Development Bank & 110 & 4 \\
World Health Organization & 483 & 1 \\
United Nations (and related units) & 760 & 6 \\
TOTAL & 2,361 & 49 \\
\hline
\end{tabular}

Literature search results and articles meeting the criteria.

The research papers and reports reviewed were published from 1992-2012. Most of these articles and reports were published after 2006 (55.1\%). Each of the year 2008, 2010 and 2011 contributed 12.24\% of the reviewed articles and reports, followed by 1993 and 2009, each contributing $8.16 \%$ respectively. The table 2 shows the reviewed publications for each year. 
Table 2. Reviewed papers and reports for each year from 1992-2012

\begin{tabular}{ccccc}
\hline Year of Publication & Publications & Percentage & $\begin{array}{c}\text { Cumulative } \\
\text { Percentage }\end{array}$ & $\begin{array}{c}\text { Reversed Cumulative } \\
\text { Percentage }\end{array}$ \\
\hline 1992 & 1 & 2.04 & 2.04 & 100 \\
1993 & 4 & 8.16 & 10.2 & 97.96 \\
1994 & 1 & 2.04 & 12.24 & 89.8 \\
1996 & 2 & 4.08 & 16.33 & 87.76 \\
1997 & 1 & 2.04 & 18.37 & 83.67 \\
1998 & 2 & 4.08 & 22.45 & 81.63 \\
1999 & 3 & 6.12 & 28.57 & 77.55 \\
2000 & 2 & 4.08 & 32.65 & 71.43 \\
2002 & 1 & 2.04 & 34.69 & 67.35 \\
2003 & 3 & 6.12 & 40.82 & 65.31 \\
2004 & 1 & 2.04 & 42.86 & 59.18 \\
2005 & 1 & 2.04 & 44.9 & 57.14 \\
2006 & 3 & 6.12 & 51.02 & 55.1 \\
2007 & 1 & 2.04 & 53.06 & 48.98 \\
2008 & 6 & 12.24 & 65.31 & 46.94 \\
2009 & 4 & 7.16 & 73.47 & 34.69 \\
2010 & 6 & 12.24 & 85.71 & 26.53 \\
2011 & 6 & 12.24 & 97.96 & 14.29 \\
2012 & 6.04 & 100 & 2.04 \\
Total & 1 & 100 & & \\
\hline & 49 & & & \\
\hline
\end{tabular}

\section{Observations and Disscussions}

\subsection{Microfinance Models}

The review revealed different models of microfinance in different countries, this observation reflects the fact that microfinance has been evolving differently in different contexts. While other countries rely on a particular model, diversities or variants exist in other countries (ADB, 2000a; 2006; Vrajlal et al., 2010). In some countries, including Nepal, Bangladesh and the Philippines, most microfinance firms utilizes Grameen model and/or it's variants. Developed and mainly used in Bangladesh, the Grameen model has long survived through cultural varieties, physical changes and institutional modifications. The distinctive features of this model includes; targeting the poor people using the means test, self selected borrower's groups usually with five members, each member guaranteeing another member's loans; savings system, often compulsory and less voluntary savings emphasis; scheduled (supportive) supervisions of groups or borrowers and finally, decentralized operations. Another model seen is the self-help groups (SHGs), this model entails larger groups of twenty or more members who are more autonomous than group members in the Grameen model. SHG operates through lending their members' savings and the group seeks fund from external sources to complement these resources. It's widely employed by a number of NGOs that promote and motivate formation of SHGs, and acting as financial or social intermediaries. The SHGs variants are also employed in such countries as Indonesia, Pakistan, Nepal and Sri Lanka (ADB, 2000a; 2006; Vrajlal et al., 2010). 


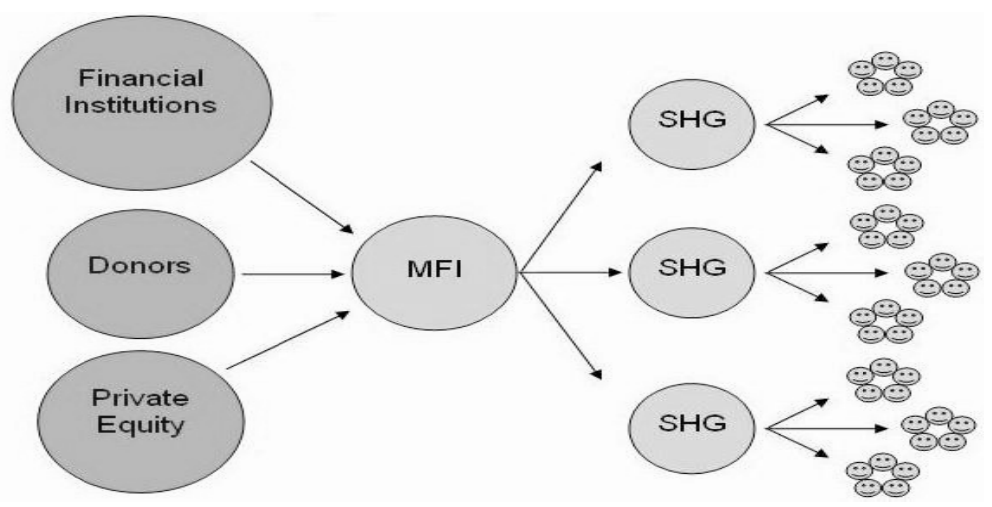

Figure 1. The self-help group microfinance model

Source: http://geopolicraticus.wordpress.com/2010/11/05/microfinance-loan-sharking/

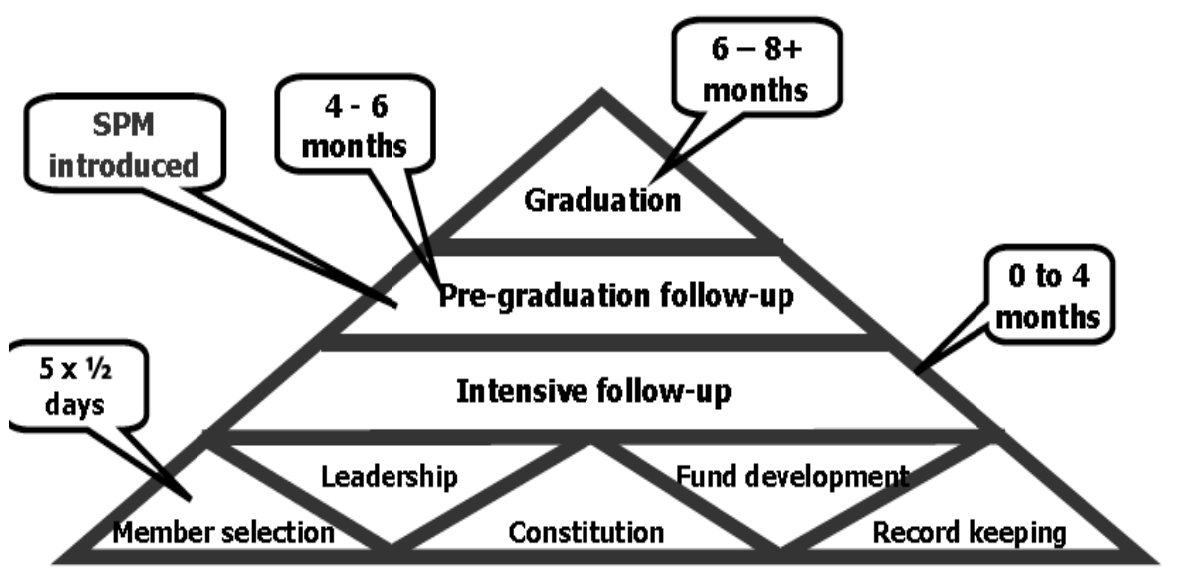

Figure 2. The CARE International Zimbabwe microfinance model. Frame for Development of KI-RMFP Savings and Loan Groups, CARE International Zimbabwe 2004.

The Credit Cooperatives union model is another type of microfinance model described in literatures. Credit cooperative societies and/or savings and credit cooperative organization (SACCOS) features microfinance in many developing countries. These societies or cooperatives operate at different local levels such as village, ward or other local levels offering savings and loans to members. In Sri Lanka for example, the district union's offers training and monitors the primary societies; the district union in turn comes under the umbrella of the larger Credit Cooperative Societies while in other countries primary union receives training and secondary loans from community banks. This movement in Sri Lanka made progress towards incorporation of poor and low-income people into its membership. It has been documented that cooperative and/or credit union movements, have sufficiently extended their services to low income and poor households (ADB, 2000a; 2006; Vrajlal et al., 2010). These three types of models described here explain the diversity seen in microfinance strategies in most countries. It is evident that one model cannot fit all circumstances (Pischke et al., 1997; ADB, 2000b; Vrajlal et al., 2010), moreover, these models are never static, they change to fit different situations. Microfinance firms tend to innovatively adopt suitable client focused model and monitors the current socio-economic, technology, and other circumstances to continually improve the existing product packages, develop new services/ products that provides better and quality services to the poor and low income people.

\subsection{Microfinance Services}

Microfinance programs are very diverse; they often range from small-scale such as self-help groups (SHGs) to large-scale financial institutions. Likewise, the microfinance models employed varies in product package, delivery, group membership structure and functions (Mayoux, 1998; 2006). Implementing a microfinance program requires selection of a financing scheme with several features. Most microfinance programs have financing scheme that provides group lending that involves the voluntary formation of small groups, loans are made to group's individual members, but all members (not individual) are responsible for loan repayment. There 
is an Incremental-lending plan that increases the loan size/amount upon successful repayment of previous loan. There is also a frequent loan repayment schedule agreed between a lending firm and the group; compulsory savings with strict withdrawal rules: and collateral or substitutes may be required. With group success over time microfinance firms may add more services including health insurance, trainings, business development and consulting services. Clearly, we can see that increasing women's access to financial resources and services consequently will support their economic empowerment (Dworkin \& Blankenship, 2009). This will not only increase their income but also improve women's well-being and sociopolitical empowerment.

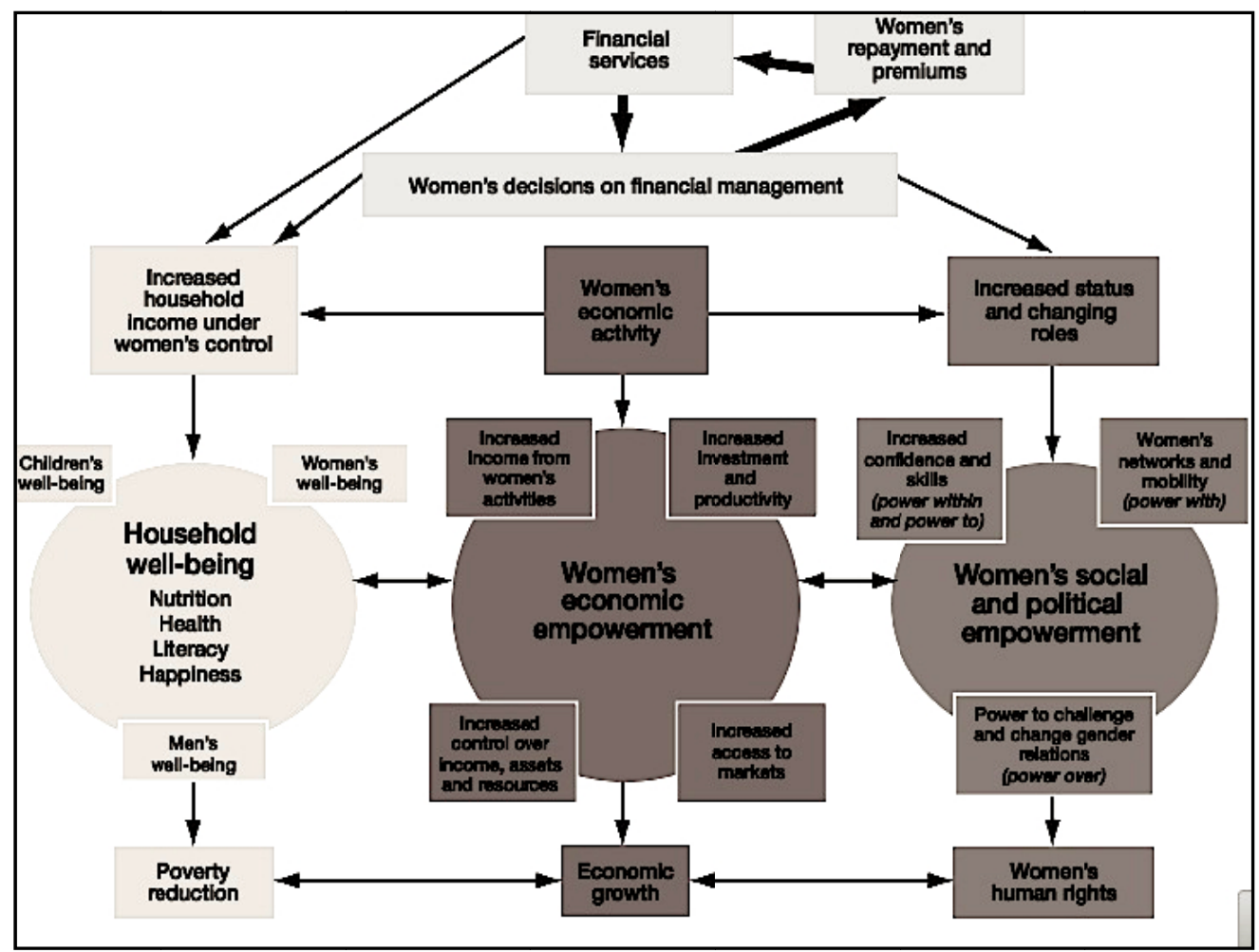

Figure 3. Microfinance and women empowerment

Source: Mayoux L and Hartl M (2009): Gender and Rural Microfinance: Reaching and Empowering women, A guide for Practitioners, IFAD, pg. 9.

\subsection{Microfinance and Gender Equity}

Women empowerment is essential for achieving gender equality. Women empowerment includes four main components: the right to have the power and control of one's own life outside and inside household settings; the right to access family and community opportunities and resources; the right to determine and pursue individual choices and a sense of self worthiness (UNFPA, 2011; Mayoux, 1998; 2006). Recent years have been characterized by a shift towards increased appreciation of gender equity especially in gender related health determinants and outcomes, role of a woman in health care related choices within and beyond family levels. A growing interest in gender sensitivity has led the gender aid and development agencies to ensure that development programs stimulates women's direct involvement in addressing issues that affecting them (Manderson \& Mark, 1997). Variations exists regarding operationalization of gender and how economical, sociopolitical and infrastructures affect woman's health or gender inequalities in microfinance projects. However varied it is, most of the programs operates by increasing women's opportunity and control over family resources, involvement and active participation in decision making process at family and community level; assistance in the designing and service delivery; management and ownership of both income generating and non income generating projects and improving literacy in order to enhance their access to skills, knowledge and capacities (Mayoux, 1998; 2006; Manderson \& Mark, 1997). Microfinance facilitates and enables women's freedom to pursue employment and maintain income (UNFPA, 2006; Mayoux, 2006). Microfinance also enables women to increase financial and non-financial assets and resources including savings, lands, business acquisition, food, 
medical care and family planning needs. Microfinance enables women's choices within household and marriage, including choices on use of earning, justification in refusing sexual intercourse and decisions about how many children to have (Schuler \& Hashemi, 1994). Hashemi et al. (1996) comments that women who participated in microfinance has significant improvement not only in decision making process at family level, but also authority and of importance, autonomy at household level. A meta analysis of the microfinance projects/programs documented in Mahmud (2003) revealed that microfinance programs/projects works best at changing the level of women's individual agency and increasing the bargaining ability and power within the household. Microfinance helps to develop self-confidence both within home and society; additionally, microfinance helps to reduce domestic violence (UNFPA, 2006).

\subsection{Microfinance and Women Health}

Microfinance scheme has been documented as the best opportunity for increasing financial and logistical accessibility of health care services to many populations which are difficult to reach especially in developing countries (Leatherman et al., 2012) and combining microfinance with other components, such as skill-based training, technical and technological support, adult education and health promotion strategies provides an opportunity for individual and family health improvement. Microfinance scheme has shown notable success in women's socio-economic empowerment and as noted by Kim et al. (2007), microfinance has contributed in reduction of intimate partner violence. Microfinance has also shown notable success in HIV Vulnerability and risk behavior reduction, on addition to its overwhelming impact on socioeconomic well-being for women (Pronyk et al., 2008). Adding a group based training component to microfinance programs increases a chance for achieving a more 'broader' health benefits (Kim et al., 2009). Surprisingly, microfinance has also been used in the fight against malaria and in mental health. De La Cruz et al. (2009) documents that, although there are several barriers in malaria control, in Ghana, malaria focused education intervention that was provided by microfinance firms contributed significantly and effectively in the success of national and community level malaria control interventions. As far as mental health is concern, Fernald et al. (2008) implies that microfinance (as a poverty alleviating tool) may be used as one of the mechanism in reducing poverty-related stress in the extremely poor people, positively affecting their psychological stress experiences and depressive symptoms. In India, development planners that design the income generation projects (IGPs) have often ignored several realities of women's living situations and often resulting in marginalizing women increasingly. In contrast, for example in Karnataka, the Women's Liberation and Rehabilitation Society (WLARS) decided to adopt a different women empowerment approach that minimize socioeconomic gaps faced by women; organize women to demand their rights, and to improve their economic status through formation of women's groups which have collective savings fund and which further the long-term goals of increasing self-reliance among women in its Income generating program. The approach has successfully reduced women's domestic workload and provided household necessities locally to reduce the need to travel to markets and have health committees that work on improving women's health and their family (Rajamma G, 1993). It's widely documented that, in addition to infection burden, women's physical, mental and social well-being is negatively affected by poor sanitation, inadequate water supply, cultural and social factors that limit their accessibility to timely and appropriate health services (Manderson \& Mark, 1997). We have to remember that the health of a woman is not only affected by her biological nature but also social and cultural barriers. In different settings, cultural, taboos and traditional practices determine the power, gender relations and roles, defines priorities and responsibilities at both household and community level consequently influencing access to skills, knowledge, capacity and material resources, all these affect women's health unfavorably. Diseases and Infections in women interfere with their work routine and functional capability at both household and income generating work; moreover, women's work nature in different communities predisposes them to ill health. Women's reproductive biological structure and function including childbearing, often compromise their health, moreover, the biological structure and functions of reproductive organs may be inversely affected by (poor) health of a woman or during pregnancy. A woman has limitations in accessing timely and adequate health care as a result of Illiteracy, inadequate Information; education; lack of ability to recognize and detect early signs and symptoms of infection sooner; health seeking behavior; financial and physical accessibility (Leslie, 1992); inadequate and inappropriate services (Mensch, 1993). Most of health programs focuses on women's health, mostly not for women's health in particular, but as a result of their social responsibility for health of their families (Allen, 1993). The Alma Ata Declaration resulted in increased focus in basic primary health services through several intersecting focus areas including employment, use of modern technology, integrating rural economic development and women empowerment, community involvement, and basic needs. Moreover, donors have prioritized programs applying these approaches, especially when women are involved from inception. 


\subsection{Microfinance and Sexual and Reproductive Health}

Countries in Sub-Saharan Africa have highest maternal death rates and morbidities and different factors interact contributing to these high rates (WHO, 2005). These factors vary from individual behavior within families and communities, education, cultural, socio-economic; resource allocation and control within families and community. Although the cost of giving birth to an infant at the health facility is mostly free in many African public health facilities, to access such health care services there are both indirect and direct costs that must be met individually. Maternal reproductive health especially pregnancy related complications are considered as the commonest causes of poverty at household level however, Abekah-Nkrumaht et al. (2011) noted that increasing women's access to financial resources such as microfinance, integrated with health education may enhance financial preparedness for women and family increasing uptake of maternal health services in Sub Saharan Africa contributing to reduction of maternal deaths. Empowering women by improving their access to micro-finance and education is important for equitable health decisions. In rural Bangladesh, a study of microfinance participants found that women participation in microfinance resulted into increased household power in reproductive health decisions such as contraceptive use (traditional and non traditional). Moreover, it was noted that women who control their own income tend to have fewer children compared to nonparticipants (Schuler \& Hashemi, 1994). Similarly, in Hays-Mitchell (1999) work in Peru, women reported enhanced control and capacity in fertility related decisions with respect to timing and birth/pregnancy spacing after participation in a microfinance program. Additionally, Mayoux (2006) affirms that, women control over family income not only increased their power to negotiate but also making sexual decisions with their male partners.

\subsection{Microfinance and HIV/AIDS}

According to UNAIDS and WHO, it was estimated that women constituted half of 34 million adults living with HIV/AIDS worldwide towards the end of 2010 (Joint United Nations Programme on HIV and AIDS [UNAIDS], 2010; 2011). The AIDS epidemic has impacted women in a unique way, accelerated by their societal responsibilities, roles, opportunities and positions in addition to vulnerabilities to Immunodeficiency virus infection biologically. Women have higher chances of acquiring HIV through sexual intercourse and are more likely to be infected, as much as twice compared to men during unprotected sexual intercourse. Women may also be receptive of infection that they may be infected by their partners as a result of their weakness in negotiating for condom use and subjected to non consensual sex (WHO, 2005; UNAIDS, 2010) Women also play a role in transmission of HIV from mother to a child (MTCT) and in many settings, they are mainly responsible for caring AIDS patients and orphans.

Different stakeholders have been implementing different programs with the aim of reducing HIV epidemic burden in women. These programs aim at protection and promotion of women focused human rights, addressing gender vulnerabilities, promoting women income, increasing education and awareness and other modern methods such as post-exposure prophylaxis and microbicides. Kim et al. (2008) recognizes that economic dependence of women on men results into increased vulnerability to HIV infections, constrains their negotiation power for issues/conditions that shape their HIV risk namely abstinence to sexual intercourse, multiple partnership and protective sex (condom). Moreover, HIV/AIDS prevention studies have shifted the focus from individual or partners/couple and small groups towards analyzing large scale social and structural determinants of the infection (Gupta et al., 2008). Poverty and gender inequality are the commonly documented structural factors for HIV/AIDS infection (Dworkin \& Blankenship, 2009) and Increasing number of studies have documented the potentially undeniable benefits of strategies for economic empowerment such as microfinance in sustained HIV-prevention and management responses (Kim et al., 2008). However, the interaction of HIV risk and poverty is "multidimensional" and somewhat "complex" thus other many factors including mobility, socio-economic inequality and socio-capital, interacts to increase women vulnerability to HIV. Moreover, even if few initiatives have combined (women) empowerment economically such as microfinance with HIV prevention explicitly (Kim et al., 2008), researchers are still recognizing and turning to microfinance interventions hoping that it may help in achieving both reduction of poverty and prevention of HIV/AIDS (Pronyk et al., 2008). Researchers have gathered more evidences on the role of microfinance on HIV Prevention for example a study reported by Rosenberg et al. (2011), which was conducted to assess the relationship of microfinance loan experience and female client HIV risk behavior in Haiti, found that clients who had longer microfinance exposure had less indicators for HIV risk and higher indicators for power in relationship. Clients with longer exposure reported lower infidelity rate, had almost four times likelihood of condom use with an unfaithful partner, and higher power index scores in contrast to shorter exposure clients. The research provided evidence that prolonged exposure to microfinance results into reduced risk of HIV in women and microfinance services such as microcredits focusing on vulnerable women potentially fosters economic independence in women, builds 
their safer sex negotiating power consequently, reducing their risks of HIV. It is also clear that women and girls who are economically disadvantaged or dependent are likely to involve themselves in risky sexual behaviors: less or unable to negotiate condom use, less likely to quit abusive/violent relationship, and have more likelihood of exchanging sex for financial and material (goods) or assets (Kim et al., 2008). Moreover, Manopaiboon et al. (2003) and Tan Minh et al. (2004) comments that, women engaging themselves in sex work are "trapped" within it mostly for financial reasons. Girls and women are more negatively affected by poverty than men with respect to unsafe sex; women financial empowerment with a target of reducing economic dependence over men is a very important predictor for women's ability to negotiating safer sex (Grieg \& Koopman, 2003). Integrating microfinance with HIV Prevention and life skill trainings provides women not only alternative income sources but also promotes economic independence and increased sexual decision making ability (Kim et al., 2008). For people living with HIV/AIDS, Microfinance is the most promising strategy for HIV/AIDS impact mitigation as far as economical vulnerability is concern (Dworking \& Blankenship, 2009). As documented by Pronyk et al. (2008), young women participated in microfinance program, displayed a higher ability in HIV communication and higher likelihood of having accessed HIV counseling and tested for their status, and reduced likelihood of having had unprotected sex in the last intercourse with a non-spousal partner. Even after two years of follow up, young participants had better results compared to controls. It is evident that combining microfinance, HIV Prevention and life skill trainings, produces synergic effects providing desired HIV prevention and risk behavior reduction compared to HIV prevention or microfinance implemented separately (Manopaiboon et al., 2003).

\subsection{Microfinance and Intimate-Partner Violence (IPV)}

Intimate Partner violence (IPV) is a worldwide problem. The World Health Organisation's Multi country Study on Women's Health and Domestic Violence against Women shows that the IPV incidence varies from one setting to another even within the very same country. A lifetime proportion women who had partners ever experienced physical and/or sexual violence, by an intimate partner ranges from $15 \%$ to $71 \%$, worldwide and, the incidences were high among women living in rural areas of Bangladesh, Ethiopia, Peru, and Tanzania (WHO, 2005). An Intervention trial with Microfinance for AIDS and Gender Equity (IMAGE) used integrated approach combining microfinance; gender and HIV training, and community mobilization activities in South Africa. The IMAGE study combined the anti-violence work, gender equity enhancing and HIV/AIDS education curriculum within existing microfinance intervention. The authors report a 55\% reduction in domestic violence after a year in intervention participants in contrast to controls (Pronyk et al., 2008; Hargreaves et al., 2010). In Bangladesh, Schuler et al. (1996) documented that the participants in the microcredit intervention were less likely to be beaten when compared to non-participants. Similarly, Hashemi et al. (1996) reported reduced incidence of IPV and that microcredit participant partner's less often hit them after participating than non-participants. Kim \&Watts (2008) considers that reduced violence was a result of a range of strategies that capacitated participants to reason, challenge and question the acceptability of violence, expecting better partner's treatment, dissolving relationships characterized by abuses, and increased community awareness on IPV. Generally, combining microfinance and a training component can result into reduction in levels of IPV (Pronkyl et al., 2008) and actually, empowering women socioeconomically particularly through microfinance contributes significantly in reducing IPV (Kim \& Watts, 2008).

\subsection{Microfinance and Family Health}

Families in sub Saharan African countries and other developing nations, are facing overwhelming financial crises in terms of medical care costs especially at a period of major illness and labour income associated losses during these crises (Murdoch, 1995). Most families rely solely on informal mechanisms, particularly in rural areas making them unable to insure health care consumption at the times of major illness (Gertler \& Gruber, 2002). Even the minimally available family financial savings and other family assets for example cow, goats, farms are often sold to self-insuring family consumption against health related emergencies and crises. Microfinance is considered as a promising strategy to help families in insuring health related consumption and making more savings. Improved access to microcredit and savings services especially in rural areas is considered to have a major role in insuring family consumption as far as theories of life cycle are concern. In Indonesia, Gertler et al. (2009), tested if access to microfinancial savings and lending firms helped families smoothen their health care financial consumption at a time of adult health decline in a household and the results, supported the contribution of these services in enabling families to self-insure for health care consumption during health shocks in the family, moreover, households closer/near the financial firms or organizations have better chances for insuring their health care consumption. The study concluded that microfinance programs have indispensable usefulness in supporting families to deal with and absorb the major health crises/shocks and emergencies; particularly with inaccessible private credit schemes. In rural areas, most individuals have no health insurance and only few are 
covered by community health insurance funds (CHIFs) that do not provide benefits upon referral to higher - level facilities and with minimal community involvement; these community funds lose members year after year. Microfinance is a promising strategy for improving family financial savings to insure sustainable health consumption over periods of major illness and emergencies.

\subsection{Consequences of Women Economic Empowerment: Risk of Family Conflicts}

Since microfinance enables women's choices within household and marriage, including choices on financial expenditures, number of children to have and sexual decisions, this may fuel family conflicts especially in rural areas where traditions and taboos are not in favor of women. Moreover, Kim et al. (2008) documented that women empowerment through microfinance interventions, initially may exacerbate intimate partner violence risk. Women involvement in activities that generate income such as businesses, agriculture, fishing for example that are male dominated traditionally, results in feelings of underpowered, resentful and exclusion (in men). Lets consider a project in Zambia for example, a project was implemented that addressed women's need only, creating imbalances and men, became restricted in accessing microloans and other benefits provided, this created resentment among men as a consequence of their inability to access the support for business and agriculture. Exclusion of men, often lead to disagreements that can lead to difficulties in implementation of program activities, consequently resulting into open or implied oppositions, lack of assistance and support to women, and sometimes efforts to diverge the resources to meet men's demand (Manderson \& Mark, 1997). Microfinance programs may result into domestic tension between partners and loss of spousal support that is usually necessary (Mayoux, 1998).

Dworkin and Blankenship (2009) documented that although some research has shown massive reduction in intimate partner violence after being exposed to a microfinance intervention, other studies show that Intimate partner violence against women increases upon participation in an economic program. A Rahman (1999) study in Bangladesh revealed that actually, domestic violence worsened following women's exposure to a micro credit program. Another observation is that microfinance institutions often creates intense pressure on loan repayment resulting into pressures that increases debt liability for the household consequently exacerbating preexisting and new marital conflicts, this finding was also reported by Hashemi et al. (1996).

Recognizing that traditions and taboos are developed over a long period of time thus requiring long-term community sensitization, microfinance programs must be tailored to community cultural and traditional context to be more successful. Using community based participatory approaches in defining cultural friendly activities are keys to program success (Israel, 2008). Although empowering women through microfinance often exacerbate intimate violence risk, there are more evidence suggesting that the violence risk may diminish over time especially if community based participatory methods were employed; prolonged exposure to the intervention; as the microfinance intervention becomes visible, acceptable and normalized in the target communities, and as tradition and cultural taboos and norms shift towards favoring women (Kim et al., 2008). Both direct and practical support from men is critical because locally, village government and administrative decisions often are under men (Manderson \& Mark, 1997) thus microfinance program should be designed in such a way that it strengthens family relationships, spouse involvement and community support.

A need for community participatory approaches to microfinance is evident. Community involvement has been documented as a promising method of designing cultural friendly and sustainable programs that fosters co-learning (Israel, 2008). Participatory approaches bring together different partners necessary for the success of the integrated program. For example Draper (1993) documented that Increased utilization of health care services was a result of microfinance combined with strategies for successful community participation, building capacity of local health workers and local birth attendants coupled with constructing a new dispensary building. Projects aiming at improving women's health rarely use community participatory approaches. Manderson \& Mark (1997), noted that when women participates in all phases of the project, from the initial needs assessment to evaluation, their capacity in designing new project and retention in the primary project is increased. Coppock et al. (2011) used action-oriented, participatory approach to engage the pastoral community to refine problem diagnosis, chart pathways for change, identify and implement interventions. This integrated the ideas, skills, and resources of numerous partners (i.e., pastoralists, researchers, development practitioners, educators, and donors) and as part of capacity building package, promoting saving culture as a means of managing financial resources through microfinance; instilling best practices in the creation and management of small businesses through micro-enterprise training; and helping generate financial capital by connecting collective-action groups to expanding livestock markets. Although, illiterate women with scant previous leadership or business experience governed the collective-action groups, members saved money and successfully managed thousands of micro loans. Interventions led to major improvements in trends for quality of life, wealth accumulation, hunger 
reduction, and risk management. Well-designed microfinance projects can enhance communities' ability to manage risk, empower women, and strengthen community ties. Community capacity-building through participatory processes can provide durable, cost-effective, and low-risk options for improving the human condition in rural areas. Community participation helps to reduce the cost of the program, for example in the study mentioned above, Coppock et al (2011); the cost of capacity-building process was about U.S. \$1 per person per month over 3 years. The low cost was due to the reliance on participatory education and peer networking.

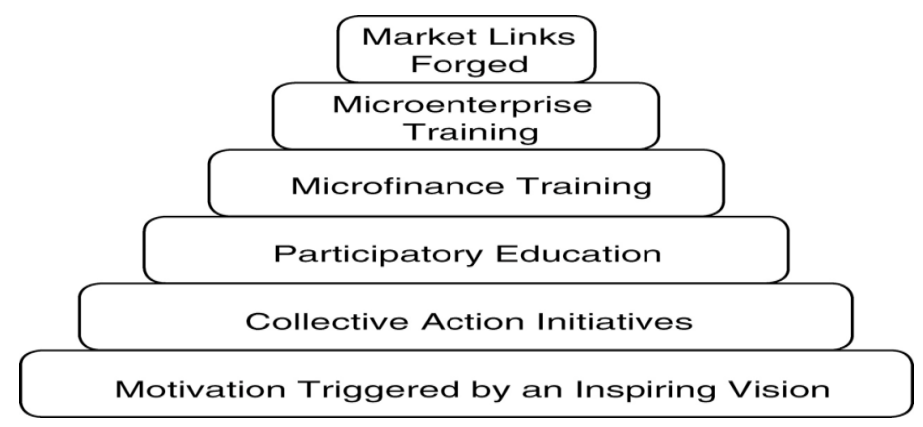

Figure 4. Step-wise participatory capacity-building interventions

Source: Coppock DL et al., Capacity building helps pastoral women transform impoverished communities in Ethiopia. Science. 2011. In this stepwise model, the cultural and social value of trained local women passed to other women from the same and neighboring communities establishes not only networks of skilled women, but also a means for them to shift their position within society, to support each other, and to increase or consolidate their spheres of influence.

\section{Conclusion and Recommendations}

From different articles, we saw that, when women control family resources, they are more likely to use them for promotion of family's health compared to men. Women income expenditure decisions, especially in rural areas more often prioritize children's diet, education and health. Women in control of their own income have fewer children, gain more control over own lives, at the same time contributes directly in their family health and development. Although microfinance programs empower women, we cannot ignore the possibility of increased marital conflicts and worsening of domestic violence against women participating in microcredit programs as noted by Dworkin \& Blankenship, 2009 and Rahman, 1999. The fact that microfinance organizations sometimes create intense pressures on women to repay loans, exacerbating preexisting and fueling new marital conflicts over loan debt payment (Hashemi et al., 1996) can not be ignored. Microfinance programs must be designed in such a way that partner support is guaranteed; healthy cultural values are preserved and if done carefully, empowerment of women significantly reduces intimate partner violence. Participatory approaches, including male involvement in need assessment, program designing and having partner focused training activities as part of integrated microfinance program guarantees not only support from partners but also strengthening the marital relationships.

It was also noted that although microfinance results in economic empowerment of women reducing their risk to sexually transmitted diseases (Hirsch et al., 2007), the resulting mobility may increase sexual risks of women with extra marital partners leading to increased possibility of sexual abuse, HIV risks and these possibilities and opportunities need to be considered before actual implementation. Thus, microfinance programs may be designed in such a way that local materials and markets are utilized to reduce mobility. In real world, its difficult to avoid mobility, thus, integrating life skills, right based, sexual and preventive education in microfinance programs may be the only feasible option. Moreover, in addition to impacts on economic well-being, reproductive health, intimate partner violence, malaria control, mental health, interventions to address the socio-economic vulnerabilities of women such as microfinance has a potential to contribute towards HIV risk behavior reduction. Thus, integrating HIV prevention trainings and microfinance, results into synergic effect that offers maximum sustainable results than prevention or microfinance program implemented alone especially when poverty is considered as a predisposing factor to HIV infection.

Despite the success of microfinance, lives of many women especially in rural areas are often unchanged by most of the interventions especially in areas where microfinance alone was implemented. We must recognize that 
other social, cultural, political, environmental factors operate continually to limit full participation of women in intervention activities and access to project services provided. This justifies a need for community based participatory 'microfinance' projects, which bring together different community partners to address the sociocultural and political challenges within the community throughout the project activities (Israel, 2008). Project beneficiaries in particular, needs to be involved in all stages of the project from the beginning; participatory approaches adds value to programs by determining community target, needs and priorities, and designing intervention of local relevance. Continued women participation from priority setting, intervention designing, implementation, monitoring, and evaluation not only maximizes the intended results but also fosters co-learning between project/program team, beneficiaries and the community. Setting realistic and community driven objectives; recognizing and enhancing status of women, and addressing gender issues are among the factors contributing to success of approaches that focuses on improving access and utilization of health care services among women.

Because, Dunbar et al. (2010) found that most businesses succeeded only when young women have had prior experience in business, have capital, have family support, and/or other top-up financial support, training women on entrepreneurship skills before actual project implementation is evident. Morduch (1995) affirms the marginally poor benefits more through microfinance, than the poorest of the poor, hence more aggressive approaches are needed to reach the poorest.

In conclusion, integration of microfinance and health education and promotion activities resulted in reduction of intimate-partner violences, reduction in HIV/AIDS risks, Malaria prevention, promotion of mental health and improved women and family health. Increasing women control over family resources will improve family health and development. Moreover, socio-economic empowerment of women contribute towards not only improved equitable family decision making but also increased family financial savings necessary during health crisis at family level.

\section{Acknowledgements}

Professor William Brieger, International Health department, The Johns Hopkins Bloomberg School of public health for advise on methodology.

Dr. Hussein Zare, a post doc fellow at the Johns Hopkins Bloomberg School of Public health for insights on systematic literature review.

\section{References}

Abekah-Nkrumah, G., Abor, P. A., Abor. J., \& Adjasi, C. K. (2011). Improving maternal healthcare utilization in sub-Saharan Africa through micro-finance. International Journal of Health Care Quality Assurance, 24(8), 601-610. http://dx.doi.org/10.1108/09526861111174170

Allen, S. (1993). Women and health in Vietnam. Development Bulletin, 26, 14-18.

ADB. (1998). Microfinance: An interim action plan. Manila. Retrived from http://www.adb.org/Publications/product.asp?sku=0177NP

ADB. (2000a). Finance for the Poor Microfinance Development Strategy. Asian Development Bank. Retrived from www.adb.org/documents/policies/microfinance/financepolicy.pdf

ADB. (2000b). The Role of Central banks in microfinance in Asia and the Pacific, The Foundation for Development cooperation. Asian Development Bank, 1.

ADB. (2006). Beyond Microfinance: Building Inclusive Rural Financial Markets in Central Asia. Asian Development Bank. Retrived from www. beta.adb.org/publications/beyond-microfinance-building-inclusive-rural-financial-markets-central-asia

Coppock, D. L., Desta, S., Tezera, S., \& Gebru, G. (2011). Capacity-building helps pastoral women transform impoverished communities in Ethiopia. Science, 334(6061), 1394-1398. http://dx.doi.org/10.1126/science. 1211232

De La Cruz, N., Crookston, B., Gray, B., Alder, S., \& Dearden, K. (2009). Microfinance against malaria: impact of Freedom from Hunger's malaria education when delivered by rural banks in Ghana. Transactions of the Royal Society of Tropical Medicine and Hygiene, 103(12), 1229-1236. http://dx.doi.org/10.1016/j.trstmh.2009.03.018

Draper, J. (1993). Mid-term review of PHC/MCH project. Sayabouri province, Lao PDR. Melbourne, Australia: Save the Children Fund Australia. 
Dunbar, M. S., Maternowska, M. C., Kang, M. J., Laver, S. M., Mudekunye-Mahaka, I., \& Padian, N. S. (2010). Findings from SHAZ: a feasibility study of a microcredit and life-skills HIV prevention intervention to reduce risk among adolescent female orphans in Zimbabwe. Journal of Prevention \& Intervention in the Community, 38(2), 147-161. http://dx.doi.org/10.1080/10852351003640849

Dworkin, S. L., \& Blankenship, K. (2009). Microfinance and HIV/AIDS prevention: assessing its promise and limitations. AIDS and Behavior, 13(3), 462-469. http://dx.doi.org/10.1007/s10461-009-9532-3

Fernald, L. C., Hamad, R., Karlan, D., Ozer, E. J., \& Zinman, J. (2008). Small individual loans and mental health: a randomized controlled trial among South African adults. BMC Public Health, 16(8), 409. http://dx.doi.org/10.1186/1471-2458-8-409

Gertler, P., Levine, D. I., \& Moretti, E. (2009). Do microfinance programs help families insure consumption against illness? Health Economics, 18(3), 257-273. http://dx.doi.org/10.1002/hec.1372

Gertler, P., \& Gruber, J. (2002). Insuring consumption against illness. American Economic Review, 92(1), 51-70. http://dx.doi.org/10.1257/000282802760015603

Grieg, F. E., \& Koopman, C. (2003). Multilevel analysis of women's empowerment and HIV prevention: Quantitative survey results from a preliminary study in Botswana. AIDS and Behavior, 7, 195-208. http://dx.doi.org/10.1023/A:1023954526639

Gupta, G. R., Parkurst, J. O., Ogden, J. A., Aggleton, P., \& Mahal, A. (2008). Structural approaches to HIV Prevention. Lancet, 764-775. http://dx.doi.org/10.1016/S0140-6736(08)60887-9

Hargreaves, J., Hatcher, A., Strange, V., Phetla, G., Busza, J., Kim, J., ... Bonell, C. (2010). Process evaluation of the Intervention with Microfinance for AIDS and Gender Equity (IMAGE) in rural South Africa. Health Education Research, 25(1), 27-40. http://dx.doi.org/10.1093/her/cyp054

Hashemi, S., Schuler, S., \& Riley, A. (1996). Rural credit programs and women's empowerment in Bangladesh. World Development, 23, 635-653. http://dx.doi.org/10.1016/0305-750X(95)00159-A

Hays-Mitchell, M. (1999). From survivor to entrepreneur: gendered dimensions of microenterprise development in Peru. Environment and Planning, 31, 251-271. http://dx.doi.org/10.1068/a310251

Hirsch, J., Meneses, S., Thompson, B., Negroni, M., Pelcastre, B., \& Del Rio, C. (2007). The inevitability of infidelity: Sexual reputation, social geographies, and marital risk in rural Mexico. American Journal of Public Health, 97(6), 986-996. http://dx.doi.org/10.2105/AJPH.2006.088492

Israel, B. A., Schulz, A. J., Parker, E. A., \& Becker, A. B. (2008). Review of Community Based Research: Assessing Partnership Approaches to Improve Public Health. Annual Review Public Health, 19, 173-202. http://dx.doi.org/10.1146/annurev.publhealth.19.1.173

Kim, J., Pronyk, P., Barnett, T., \& Watts, C. (2008). Exploring the role of economic empowerment in HIV prevention. AIDS, 22, S57-S71. http://dx.doi.org/10.1097/01.aids.0000341777.78876.40

Kim, J. C., Ferrari, G., Abramsky, T., Watts, C., Hargreaves, J., Morison, L., ... Pronyk, P. (2009). Assessing the incremental effects of combining economic and health interventions: the IMAGE study in South Africa. Bull World Health Organ, 87(11), 824-832. http://dx.doi.org/10.2471/BLT.08.056580

Kim, J. C., Watts, C. H., Hargreaves, J. R., Ndhlovu, L. X., Phetla, G., Morison, L. A., ... Pronyk, P. (2008). Understanding the impact of a microfinance based intervention on women's empowerment and the reduction of intimate partner violence in South Africa. American Journal of Public Health, 97, 1794-1802. http://dx.doi.org/10.2105/AJPH.2006.095521

Leatherman, S., Metcalfe, M., Geissler, K., \& Dunford, C. (2012). Integrating microfinance and health strategies: examining the evidence to inform policy and practice. Health Policy Planning, 27(2), 85-101. http://dx.doi.org/10.1093/heapol/czr014

Leslie, J. (1992). Women's time and the use of health services. IDS Bulletin, 23(1), 4-7. http://dx.doi.org/10.1111/j.1759-5436.1992.mp23001002.x

Mahmud, S. (2003). Actually how empowering is microcredit. Development and Change, 34, 577-605. http://dx.doi.org/10.1111/1467-7660.00320

Manderson, L., \& Mark, T. (1997). Empowering women: participatory approaches in women's health and development projects. Health Care Women International, 18(1), 17-30. http://dx.doi.org/10.1080/07399339709516256 
Manopaiboon, C., Bunnell, R. E., Kilmarx, P. H., Chaikummao, S., Limpakarnjanarat, K., Supawitkul, S., ... Mastro, T. D. (2003). Leaving sex work: Barriers, facilitating factors, and consequences for female sex workers in northern Thailand. AIDS Care, 15, 39-52. http://dx.doi.org/10.1080/012021000039743

Mayoux, L. (1998). Research Round-Up women's empowerment and micro-finance programmes: strategies for increasing impact. Development in Practice, 8(2), 235-241. http://dx.doi.org/10.1080/09614529853873

Mayoux, L. (2006). Women's empowerment through sustainable microfinance: Rethinking best Practice. Gender and Microfinance. Retrived from http://www.mtnforum.org/sites/default/files/pub/3849.pdf

Mensch, B. (1993). Quality of care: A neglected dimension. In M. Koblinsky, J. Timyan, \& J. Gay (Eds.), The health of women. A global perspective (pp. 235-253). Boulder, CO: Westview Press.

Morduch, J. (1999). The microfinance promise. Journal of Economic Literature, 37, 1569-1614. http://dx.doi.org/10.1257/jel.37.4.1569

Nawaz, S. (2010). Microfinance and poverty reduction: evidence from a village study in Bangladesh. Journal of Asian African Studies, 45(6), 670-683. http://dx.doi.org/10.1177/0021909610383812

Pronyk, P. M., Kim, J. C., Abramsky, T., Phetla, G., Hargreaves, J. R., Morison, L. A., .. Porter, J. D. (2008). A combined microfinance and training intervention can reduce HIV risk behaviour in young female participants. AIDS, 22(13), 1659-1665. http://dx.doi.org/10.1097/QAD.0b013e328307a040

Rahman, A. (1999). Women and microcredit and rural Bangladesh: An anthropological study of Grameen bank lending. Boulder: Westview Press.

Rajamma, G. (1993). Empowerment through income-generating projects. Journal of Gender and Development, 1(3), 53-55. http://dx.doi.org/10.1080/09682869308519985

Rosenberg, M. S., Seavey, B. K., Jules, R., \& Kershaw, T. S. (2011). The roles of a microfinance program on HIV risk behavior among Haitian women. AIDS and Behavior, 15(5), 911-918. http://dx.doi.org/10.1007/s10461-010-9860-3

Schuler, S. R., \& Hashemi, S. M. (1994). Credit programs, women's empowerment, and contraceptive use in rural Bangladesh. Studies in Family Planning, 25, 65-76. http://dx.doi.org/10.2307/2138085

Schuler, S. R., Hashemi, S. M., Riley, A. P., \& Akhter, S. (1996). Credit programs, patriarchy, and men's violence against women in rural Bangladesh. Social Science and Medicine, 43, 1729-1742. http://dx.doi.org/10.1016/S0277-9536(96)00068-8

Tan Minh, T., Thi Nhan, D., West, G. R., Durabnt, T. M., Jenkins, R. A., Thi Huong, P., Valdiserri, R. O. (2004). Sex workers in Vietnam: How many, how risky? AIDS Education and Prevention, 16, 389-404. http://dx.doi.org/10.1521/aeap.16.5.389.48740

UNAIDS. (2010). UNAIDS report on the global AIDS epidemic. Retrived from http://www.unaids.org/globalreport/Global_report.htm

UNAIDS. (2011). World AIDS Day Report 2011. Retrived from http://www.unaids.org/en/media/unaids/contentassets/documents/unaidspublication/2011/JC2216_WorldAI DSday_report_2011_en.pdf

UNDP. (2011). Human Development Report 2011:Sustainability \& Equity: A better future for All. New York, USA. Retrived from http://hdr.undp.org/en/media/HDR_2011_EN_Contents.pdf

UNFPA. (2006). From Microfinance to Macro Change: Integrating Health Education and Microfinance to Empower Women and Reduce Poverty. Retrived from http://www.unfpa.org/upload/lib_pub_file/530_filename_advocacy.pdf

UNFPA. (2011). Exploring Linkages: Women's empowerment, microfinance and Health Education. Retrived from http://www.unfpa.org/public/home/publications/pid/7262 on 7th January 2012

United Nations. (2010). The World's Women 2010: Trends and Statistics. Department of Economic \& Social Affairs, New York, USA. Retrived from http://unstats.un.org/unsd/pubs/gesgrid.asp?id=428

Vrajlal, K. S., Kandarp, V. P, \& Sweta, V. P. (2010). Micro Finance Models. Germany: Lambert Academy Publishing. Retrived from http://works.bepress.com/vrajlal_sapovadia/34/

WHO. (2005). Multi-country study on women's health and domestic violence against women: summary report of initial results on prevalence, health outcomes and women's responses. Geneva, World Health Organization. 